\title{
W24-(1) 化学プラントのモニタリングによる信頼性確保
}

旭化成 中原正大

1.はじめに

本報告では、化学プラントにおけるモニタリングの目的、方法、具体例、課題に関して紹介する。 2 . 目的

運転中に装置材料に機械的もしくは化学的（腐食や高温劣化）劣化や損傷の進行する可能性があ る場合に、モニタリングは行われる。材料劣化や損甥が進行により製品品質の確保や連続運転が困 難となる可能性があり、また安全運転に支障を来すこともある。このため、運転中に発生可能性の ある劣化現象に対して適切な手法を採用し、監視を行うのがモニタリングである。

3、モニタリング方法

表 1.モニタリング方法の例とその特徽

\begin{tabular}{|c|c|c|c|c|}
\hline \multirow[t]{2}{*}{ 手法 } & \multicolumn{2}{|r|}{ 対象の現象 } & \multicolumn{2}{|c|}{ 特街 } \\
\hline & 性質 & 名称 & 長所 & 短所 \\
\hline 電気抵抗 & \multirow{5}{*}{ 腐食 } & 全面腐食量 & $\begin{array}{l}\text { 装置が市販. 全ての環 } \\
\text { 境で測定可能 }\end{array}$ & $\begin{array}{l}\text { センサが主要材料に限 } \\
\text { 定. }\end{array}$ \\
\hline 分極抵抗 & & 全面腐食速度 & $\begin{array}{l}\text { 腐食速度が直接測定可 } \\
\text { 能. 装置が市販. }\end{array}$ & $\begin{array}{l}\text { 伝導性溶液環境に測定が } \\
\text { 限定. }\end{array}$ \\
\hline 電位測定 & & 腐食状態 & 測定が容易. & $\begin{array}{l}\text { 電位と現象との対応の明 } \\
\text { 確化要. 適用電極要. }\end{array}$ \\
\hline 試験片設置 & & 種々の腐食形態 & 測定が容易. & $\begin{array}{l}\text { 取り出すまで評価不能. } \\
\text { 時間の積分值を評価. }\end{array}$ \\
\hline 環境測定、分析 & & 種々の腐食可能性 & 多くの環境で適用可. & $\begin{array}{l}\text { 測定值と現象の対応の明 } \\
\text { 確化要. }\end{array}$ \\
\hline 超音波（板厚） & \multirow{2}{*}{$\begin{array}{l}\text { 腐食、 } \\
\text { 機械 }\end{array}$} & \multirow[t]{2}{*}{ 全面腐食、磨耗 } & \multirow{2}{*}{$\begin{array}{l}\text { 測定精度が比較的高く } \\
\text { 容易. }\end{array}$} & \multirow{2}{*}{$\begin{array}{l}\text { オフラインの測定となる } \\
\text { 場合が多い. }\end{array}$} \\
\hline $\mathrm{X}$ 線 (板厚) & & & & \\
\hline 超音波（ノイズ） & $\begin{array}{l}\text { 高温劣 } \\
\text { 化 }\end{array}$ & 水素侵食 & $\begin{array}{l}\text { 高温センサーを利用し } \\
\text { て進行評価可能. }\end{array}$ & $\begin{array}{l}\text { 温度や場所による制約有 } \\
\text { り. }\end{array}$ \\
\hline 伝導度計 & 腐食 & Ta の水素脆化 & 脆化程度を評価可能 & オフラインの測定となる \\
\hline 超音波（斜角） & $\begin{array}{l}\text { 腐食、 } \\
\text { 機械 }\end{array}$ & 腐食割れ、疲労 & $\begin{array}{l}\text { 割れ進行のモニタリン } \\
\text { グ可能. }\end{array}$ & $\begin{array}{l}\text { 装直の形状や部位による } \\
\text { 制約有り. }\end{array}$ \\
\hline 表面粗さ & \multirow[t]{2}{*}{ 機械 } & 疲労 & $\begin{array}{l}\text { 割れ発生以前の疲労蓄 } \\
\text { 積の評価可能. }\end{array}$ & $\begin{array}{l}\text { 粗さと疲労の蓄積に関す } \\
\text { るデータ要. オフライン } \\
\text { の測定となる場合が多い }\end{array}$ \\
\hline 振動計 & & $\begin{array}{l}\text { 振動（疲労可 能 } \\
\text { 性） }\end{array}$ & $\begin{array}{l}\text { 方向や振幅の定量化可 } \\
\text { 能 }\end{array}$ & $\begin{array}{l}\text { 振動と材料劣化の関係の } \\
\text { 明確化要. }\end{array}$ \\
\hline
\end{tabular}

具体的な例を幾つか紹介する。

（1） 1/2Mo 鋼の水素侵食のモニタリング：設計時点でのネルソン線図では、水素侵食の発生し

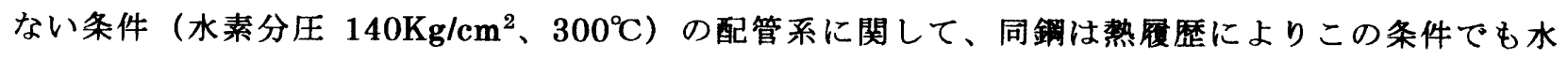


素侵食発生可能性があるとの情報を元に定期検查時に一部サンプリングによる破壞検査 ${ }^{1)}$ と超音 波による評価（林状エコー法）を実施した。その結果、サンプルに軽度ながら水素侵食の発生が確 認され、同時に行った超音波測定より配管の一部に水素侵食発生部が検出された。この部分の水素 侵食の顕在化している厚さは、板厚の 2 割以下であり、この部位はすでに 20 年同じ環境条件で使 用されていた。このため、運転中の水素侵食の進行を高温用超音波センサーにて定期的に評価した。 その結果、水素侵食の厚さは二年間変化せず、その時点で更新された。

(2) 脱炭酸系での電位モニタリング2)：炭酸 カリを吸収液とする、水素と二酸化炭素の分離 を目的としてプラントでは、炭素鋼製装置の腐 食を防止するために酸化剤が添加されている。 従来、酸化剤の濃度の化学分析で防食性を確認 していた。しかし、即応性や簡便性に問題があ った。このため、分極特性による解析を行い図 1 に示す様に、各 $\mathrm{pH}$ における電位の安全域を 明らかにした。この図をマスター線図として、 電位のモニタリングにより本プロセスの腐食を 抑制している。

（3）タンタルベルト製部材の水素脆化のモニ タリング3)：高温の中濃度硫酸環境で使用して いるタンタル製部材に水素脆化による割れが発 生した。このため、水素脆化の程度と伝導度の 関係を図 2 に示し通り明らかにした。この関係 図を基に、定期的に伝導度を非破壊的に評価し、 水素脆化の程度を関している。なお、水素脆化 の発生した部材は、高温真空熱処理により脱水 素を行い、再使用している。

\section{4. 今後の課題}

化学産業は、設備の老朽化の進行、保全担当 者の世代交代や省力化があり、適正な設備管理 が今後ますます必要となる。これを支える要素 技術として、モニタリングを適切に活用するこ

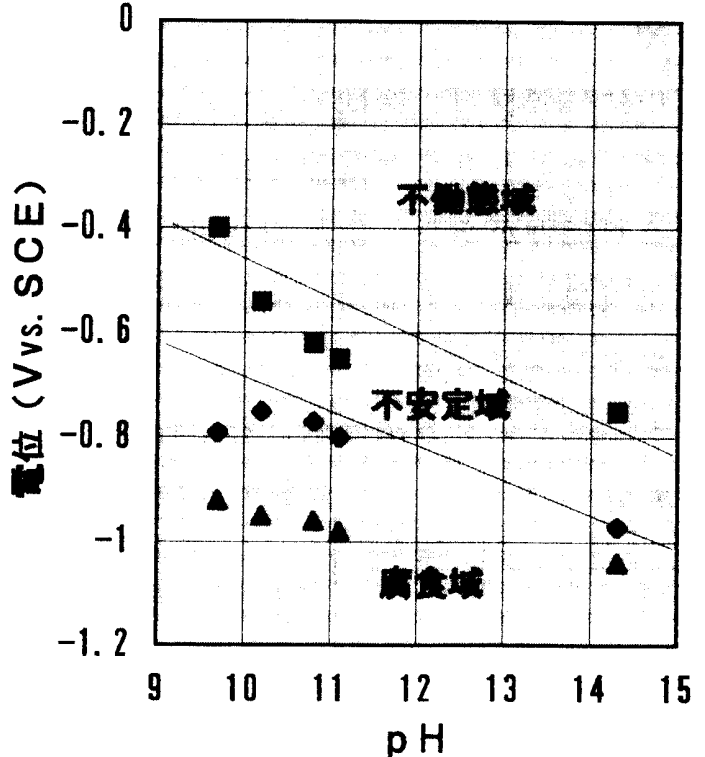

図 1. 脱炭酸系での $\mathrm{pH}$-電位領域での防食域

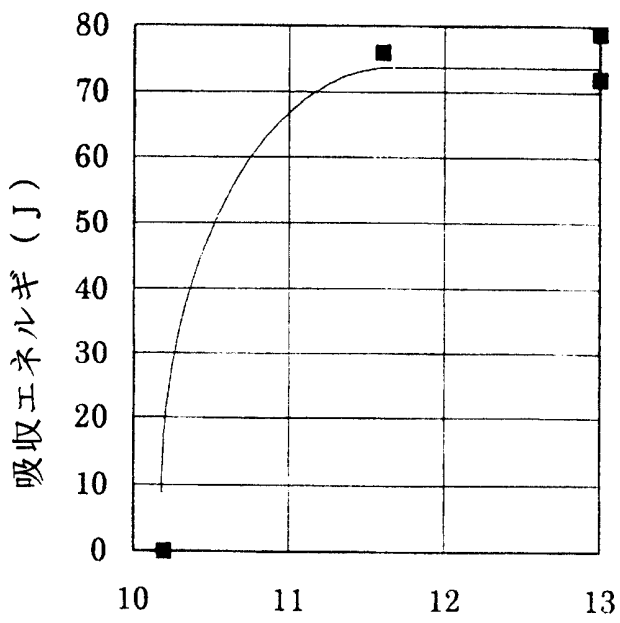

電気伝導度 (IACS\%)

図 2.タンタルの電気伝導度と勒性（シャル ピー吸収エネルギ）の関俰 とが重要である。このためのモニタリング事例の蓄積、情報や技術の共有化、および技術の開発が 必要と考えられる。

参考文献：（1）中原正大：第 41 回腐食防食討論会、p.365（1994）.（2）中原正大：シンポ ジウム「化学装置の信頼性確保のための技術」化学工学会、（1995）（3）中原正大、庄子哲雄： 日本機械学会論文集（A編）、62 巻 595 号、p.707（1996） 